\title{
Assessing Organizational Culture: An Important Step for Enhancing the Implementation of Junior High School-Based Pesantren
}

\author{
Muhammad Anggung Manumanoso Prasetyo', Khairul Anwar² \\ DOI: $10.35445 /$ alishlah.v13i1. 461
}

\section{Article Info}

Keywords:

Organizational Culture

Implementasi

Islamic Education

Pesantren

\begin{abstract}
Pesantren is required to be competitive in the field of science. The presence of the SMP-BP program is one of the efforts to improve science education in Islamic boarding schools. Leadership and culture are essential factors in encouraging the level of organisational management effectiveness. This article aims to deepen knowledge of practices in pesantren culture and its dynamics concerning the effectiveness of pesantren organisations (SMP-BP implementation). The research paradigm is qualitative. Data is obtained through interviews and observations. This research involved pesantren managers consisting of leaders, deputy leaders, and several pesantren teachers in Aceh Tenggara district. This research is necessary because it examines a culture in a practical perspective that visualises and concretises the complexities in Islamic boarding school culture concerning the dynamics of work improvement. The results showed that the formation of pesantren culture is a fundamental principle in creating organisational effectiveness. This study investigates the forms of practice carried out by pesantren managers in increasing organisational effectiveness. Identifying the improvement in the management of pesantren is influenced by the policy factors of the pesantren leadership. Three practices identified in an organisational culture approach are leadership mechanisms, management revitalisation, change commitment, and building organisational culture. The research has implications as material for further studies on strengthening organisational culture both contextually and conceptually on the dynamics of education management.
\end{abstract}

\begin{abstract}
Abstrak
Pesantren dituntut kompetitif dalam bidang sains. Kehadiran program SMP-BP menjadi salah satu upaya peningkatan pendidikan sains di pesantren. Kepemimpinan dan budaya adalah faktor penting untuk mendorong tingkat efektivitas pengelolaan organisasi Artikel ini bertujuan untuk memperdalam pengetahuan praktik dalam budaya pesantren dan dinamikanya dalam kaitannya dengan efektivitas organisasi pesantren (pelaksanaan SMP-BP). Paradigma penelitian adalah kualitatif. Data diperoleh melalui hasil wawancara dan observasi. Penelitian ini melibatkan pengelola pesantren yang terdiri dari pimpinan, wakil pimpinan, dan beberapa guru pesantren di kabupaten Aceh Tenggara. Penelitian ini menjadi penting karena mengkaji budaya dalam perspektif praktik yang memvisualisasikan dan mengkonkretkan kompleksitas dalam budaya pesantren dalam kaitannya dengan dinamika perbaikan kerja.
\end{abstract}

\footnotetext{
${ }^{1}$ IAIN Lhokseumawe, Lhokseumawe- Aceh, Indonesia

Email: anggung@iainlhokseumawe.ac.id

2 Institut Agama Islam Tebo, Jambi, Indonesia

Email: alkhair2505@gmail.com
} 
Hasil penelitian menunjukkan bahwa pembentukan budaya pesantren sebagai azas fundamental dalam menciptakan efektivitas organisasi. Penelitian ini menyelidiki bentuk praktik yang dilakukan pengelola pesantren dalam meningkatkan efektivitas organisasi. Identifikasi peningkatan pengelolaan pesantren dipengaruhi faktor kebijakan pimpinan pesantren. Tiga praktik yang diidentifikasi dalam konteks pendekatan budaya organisasi adalah mekanisme kepemimpinan, revitalisasi manajemen, komitmen perubahan dan membangun budaya organisasi. Penelitian berimplikasi sebagai bahan kajian lebih lanjut terhadap penguatan budaya organsiasi baik secara kontekstual dan konseptual pada dinamika pengelolaan pendidikan.

\section{PENDAHULUAN}

Sistem pendidikan yang berkembang di Indonesia terbagi dua, pendidikan umum diwakili sekolah dan pendidikan keagamaan oleh madrasah dan pesantren. Tantangan terhadap pendidikan agama menjadi berat dengan meningkatnya kompleksitas tuntutan terhadap lembaga pendidikan Islam. Dalam hal ini pesantren dianggap kurang kompetitif dalam bidang keilmuan sains. Hal tersebut selaras dengan idealisme pesantren berusaha mempertahankan nilai-nilai yang sudah ada (pembelajaran kitab) disisi lain upaya terhadap tuntutan globalisasi (pendidikan formal) pendidik (Tolchah \& Arfan Mu'ammar, 2019) (Indra, 2017) (Asrori, 2020).

Mengacu pada landasan yuridis UU No.2 tahun 1989, pesantren secara legal dapat menyelenggarakan pendidikan formal seperti sekolah atau madrasah. Hal tersebut sangat mendasar, karena pesantren berupaya menyelenggarakan pendidikan yang seimbang yaitu mengakomodir kebutuhan dunia dan kebutuhan agama (Subagia, 2010). Agar tidak terkesan eksklusif pesantren dituntut adaptif terhadap perubahan sebagaimana penelitian Kantavong, (2018) sekolah yang kompetitif adalah yang bersifat inklusif artinya tidak menutup diri terhadap perubahan. Dalam konteks ini pemerintah hadir melalui Kerjasama Kemenag dengan Kemdiknas dalam penyelenggarakan program Sekolah Menengah Pertama Berbasis Pesantren (SMP-BP) yaitu sebuah program untuk meningkatkan kualitas pembelajaran sains di pesantren. Disisi lain pihak internal pesantren berusaha memenuhi ekspektasi masyarakat dengan melakukan pengembangan kelembagaan melalui revitalisasi sistem dan integrasi kurikulum sains dan agama.

Dalam integrasi pendidikan formal pesantren dapat menyelenggarakan sistem sekolah umum meski mayoritas pesantren berafiliasi dengan madrasah. Alasannya pelaksanaan pembelajaran di madrasah lebih linear karena konsep integrasi ilmu sains dan nilai keIslaman (Fajar, 2011). Guna menyeimbangkan hal tersebut dilakukan revitalisasi pendidikan dalam ranah manajerial pesantren melaksanakan program inovatif yaitu melalui program sekolah berbasis pesantren. Program SMP BP merupakan manifes dari proses integrasi sains dengan nilai KeIslaman yang diusahakan oleh Kemenag dan Kemendikbud. Nilai tambah tersebut merupakan usaha pesantren dalam memenuhi tuntutan masyarakat agar mutu lulusan lebih kompetitif atau mampu bersaing di bidang sains.

Perubahan paradigma pengelola pesantren sebagai bentuk perwujudan integrasi sains dengan nilai agama (baca Islamisasi ilmu pengetahuan) dapat memberikan legitimasi teologis yang berdampak pada integrasi kurikulum khususnya jenjang pendidikan formal yang berada di pesantren. Selain itu, program SMP-BP menitik beratkan pada pembentukan karakter dengan ketajaman akal. Harapan ke depan pesantren mampu tampil sebagai pioneer proyek pendidikan karakter yang menjawab segala permasalahan pendidikan (Dacholfany, 2015). Sebagaimana penelitian Abu Bakar et al, (2019) pengetahuan manajerial menentukan kebijakan yang diambil dan mempengaruhi kinerja organisasi. Pentingnya paradigma pimpinan yang terbuka terhadap perubahan tercermin melalui kebijakan pimpinan pesantren untuk berpartisipasi dalam pelaksanaan program SMP-BP. Hasil observasi awal menunjukkan beberapa pesantren di Kabupaten Aceh Tenggara berpartisipasi aktif dalam menyelenggarakan program SMP-BP. 
Pola-pola yang demikian inilah akhirnya menjadi suatu bentuk tata kelola (manajemen) sumber daya organisasi yang secara efektif berorientasi pada pemenuhan tujuan organisasi. Artinya, budaya tersebut membentuk tatanan normatif pada sistem manajemen dalam organisasi yang pada sisi filosofis organisasi serta operasionalisasinya mengacu pada penerapan nilai dan norma, pembentukan sistem, keyakinan, dan varian-varian lain yang ada dalam budaya organisasi (Cacciattolo, 2014). Kebijakan pemerintah terkait pesantren belum optimal. Ketidak seimbangan tersebut merupakan akumulasi dari paradigma pengelola pesantren sendiri yang masih konservatif, artinya masih banyak pimpinan pesantren yang menutup diri terhadap perubahan (Hidayah \& Prasetiya, 2019). Akibatnya pesantren urung melakukan modernisasi kurikulum sehingga terlihat semakin kental jurang kesenjangan dengan pendidikan umum dalam masalah prestasi sains. Kesenjangan tersebut kemudian membentuk anggapan pesantren hanya sebuah lembaga informal tanpa kesesuaian standar mutu pendidikan (Green, 2012)(Hasyim, 2015). Sekolah yang melaksanakan program SMP-BP di Kabupaten Aceh Tenggara ada empat, dalam hal ini yang menjadi lokus penelitian adalah pesantren Darul Amin dan Darul Azhar mengacu pada kuantitas dan mutu pesantren dalam lingkup kabupaten Aceh Tenggara.

Budaya memiliki implikasi yang jelas untuk peningkatan kualitas kinerja organisasi (Sergiovanni \& Green, 2015). Budaya berdampak positif kepada seluruh masyarakat organisasi baik guru atau murid (Jerald, 2012). Budaya organisai adalah tentang nilai dan ibarat ruh bagi sekolah (Hinde \& Stringer, 2012) yang mempengaruhi pikiran, perasaan, dan tindakan seseorang, bahkan setiap aspek sekolah (Recepoğlu, 2013). Sebagai bentuk adaptif sekolah agar tetap kompetitif adalah melakukan perubahan baik dalam sistem pengelolaan maupun struktur kelembagaan. Agar perubahan berdampak konstruktif maka harus mengacu pada nilai organisasi yang sudah ada di pesantren, hal itu juga menjadi pedoman agar pesantren tidak kehilangan arah asumsi tersebut sejalan dengan hasil penelitian (Liedtka \& Kaplan, 2019) (Marcia et al., 2012), secara korelatif budaya organisasi akan semakin kuat dengan adanya perubahan yang fungsional. Dalam kaitannya dengan perubahan, kajian penelitian diperkuat juga oleh penelitian AL-Abrrow et al, (2019) yang mengemukakan menemukan adanya korelasi antara aspek budaya organisasi dengan kepemimpinan, dan kinerja organisasi. Melalui kajian ini diharapkan memberi jawaban berkaitan aspek manajemen pesantren ditinjau dari problemtaika terkait masalah efektivitas organisasi.

\section{METODE}

Metode yang digunakan berjenis kualitatif dengan pendekatan survei. Survei dilakukan untuk memperoleh data penentu efektivitas pelaksanaan program SMP-BP yang dilakukan melalui wawancara non terstruktur. Selain itu observasi partisipan juga digunakan untuk validasi data. Adapun tempat penelitian dilakukan pada pesantren di Aceh Tenggara sebagai sebagai penyelenggara program SMP Berbasis Pesantren (BP). Dalam penelitian ini adalah pesantren Darul Amin dan Darul Azhar. Bertindak sebagai informan utama dalam penelitian ini adalah pimpinan dan guru pesantren. Pengumpulan data dilakukan dengan teknik angket, wawancara, dan diskusi kelompok terfokus (FGD). Dalam merumuskan asumsi-asumsi penelitian ini ditempuh melalui telaah berbagai konsep dan teori yang berkaitan dengan proses pengembangan budaya dan faktorfaktor yang mempengaruhi efektivitas organisasi. Validasi data menggunakan model triangulasi, dimana peneliti mengecek kebenaran data atau informasi yang diperoleh peneliti dari berbagai sudut pandang yang berbeda dengan cara mengurangi sebanyak mungkin bias yang terjadi pada saat pengumpulan dan analisis data (Cresswell, 2012) (Bungin, 2018) (Turner, 1983).

\section{HASIL PENELITIAN DAN PEMBAHASAN}

Program SMP-BP merupakan program integratif untuk meningkatkan kualitas pesantren dalam bidang Sains. Proses pelaksanaan tersebut menuntut peran integrative seluruh komponen masyarakat pesantren baik guru maupun tenaga kependidikan. Bobot tanggung jawab pelakupelaku tersebut akan berbeda satu dengan lainnya dan merupakan diskusi penting pada sub bahasan ini. Program SMP-BP dilaksanakan sesuai kontrak selama setahun. Konsistensi penguatan program 
tergantung pada ketersediaan sumber daya masing-masing pesantren. Dari data penelitian melalui wawancara diketahui bahwa pesantren mengalami keterbatasan pada sumber pembiayaan sehingga peranan masing-masing sangat menentukan kesuksesan program BP. Oleh karena itu target yang harus dicapai agar program berjalan secara berkesinambungan adalah membangun budaya organisasi. Budaya disini adalah miliu pembelajaran yang merubah paradigma santri yang anti terhadap pelajaran sains.

Menjadi produktif dalam konteks budaya sekolah menuntut keterampilan dan keahlian, yang paling krusial adalah keahlian memimpin. Masyarakat organisasi sadar betul bahwa penciptaan budaya selain dipengaruhi kepemimpinan juga tetap mendasarkan pada budaya lama yang dimilikinya. Untuk itu perlu adanya keseimbangan dalam proses tersebut sehingga revitalisasi sistem manajemen terhadap perubahan menjadi penting untuk dilakukan. Hasil penelitian secara garis besar terbagi menjadi 3 bahasan yaitu tinjauan terhadap aspek kepemimpinan, sistem manajemen, dan komitmen perubahan.

\section{Kepemimpinan Membangun Budaya Organisasi}

Komponen yang paling fundamental dalam pengelolaan pesantren adalah faktor kepemimpinan. Sebagai penentu arah pemimpin berperan dalam proses penataan dan pengelolaan pesantren yang melibatkan masyarakat pesantren dalam upaya mencapai tujuan yang efektif dan efisien. Kompetensi manajerial pesantren merupakan kemampuan dasar seorang pemimpin. Dalam upaya tersebut Pimpinan pesantren secara jelas memiliki perencanaan yang matang, pembagian tugas yang proporsional dan sistem evaluasi yang memadai. Semakin baik kompetensi manajerial pimpinan pesantren maka semakin baik pengelolaan pesantren, asumsi tersebut diperkuat oleh penelitian (Fauziah, 2018) (Arikunto, 2019).

Linearitas tersebut disebabkan individu di pesantren mengetahui tugas yang dibebankan kepadanya sehingga mampu membuat perencanaan target dalam mencapai tujuan tersebut. Kepemimpinan pada pesantren Darul Amin dan Darul Azhar mengindikasikan gaya kepemimpinan visioner dan partispatif. Visioner karena turut berpartisipasi terhadap pelaksanaan program SMPBP dan partisipatif karena mengakomodir tuntutan masyarakat terhadap peningkatan mutu lulusan dengan indicator kompetitif dalam bidang keahlian sains.

Mengacu dari proses pendidikan yang dilaksanakan Guru dalam implementasi program SMPBP menaruh perhatian penting dalam masalah pembelajaran. Pembelajaran akan terlaksana dengan baik apabila guru mampu melaksanakan perencanaan hingga melakukan evaluasi terhadap proses pembelajaran yang dilaksanakan sehingga dapat meningkatkan kinerjanya yang berdampak pada organisasi.

Kepemimpinan tidak terlepas dari kompetensi pimpinan dalam aspek manajerial. Kompetensi adalah penerapan beberapa skill dalam peranan spesifik untuk mencapai efektivitas organisasi (Lassnigg, 2017) (Mukhtar et al., 2019). Dalam lingkup personal, guru dan karyawan di pesantren butuh pengetahuan diri, pengetahuan publiknya, materinya, metodenya. Gaya kepemimpinan Kyai atau pimpinan pesantren tidak monoton kepada satu gaya melainkan bersifat situasional. Secara dominan seorang Kyai memiliki karisma yang mampu mempengaruhi guru di pesantren, tetapi juga banyak kyai muda mengarah kepada gaya kepemimpinan transformatif dan inovatif (Pertiwi et al., 2018) (Alam, 2018). Dalam perhatiannya terhadap proses implementasi progam SMP-BP Kyai berperan dalam melakukan monitoring pembelajaran. Beberapa upaya yang dilakukan antara lain dengan mengadakan kunjungan kelas, melaksanakan pertemuan pribadi, mengadakan rapat dewan guru, melakukan pertemuan kelompok kerja, serta mengadakan pendidikan, pelatihan serta pembinaan guru khususnya bagi guru yang lemah dalam pengajaran sains.

Penguatan kepemimpinan sangat penting karena hal itu berpengaruh terhadap penanaman nilai-nilai sebuah budaya organisasi baik di sekolah maupun di pesantren. Beberapa penelitian terkini menunjukkan kontribusi signifikan aspek kepemimpinan terhadap kualitas dan efektivitas 
pencapaian budaya organisasi. Pembahasan tentang kepemimpinan yang bervariasi dalam konteks dan budaya menyimpulkan bahwa nilai-nilai kejujuran, integritas, kebenaran, serta kedalaman emosi dan pribadi pada semua personel organisasi merupakan faktor utama dalam keberhasilan praktik kepemimpinan dalam suatu organisasi tidak terkecuali pesantren penyelenggara program SMP-BP.

Budaya organisasi adalah pola asumsi dasar yang diciptakan, ditemukan dan dikembangkan oleh kelompok tertentu untuk mengatasi masalah adaptasi eksternal dan integrasi internal yang resmi terlaksana dan diwariskan kepada anggota baru dalam menjalankan kewajiban dan berperilaku (Schein, 2004).

Dalam pelaksanaan program SMP-BP konsep kepemimpinan harus dimaknai secara luas, artinya peran kepemimpinan tidak terbatas menyangkut masalah kebijakan saja melainkan mencangkup komponen manajerial mulai dari perencanaan hingga evaluasi sehingga relevan dengan kehidupan nyata serta trennya. Dalam konteks trend komunitas, kepemimpinan lebih cenderung diarahkan pada strategi yang diambil oleh seorang pemimpin organisasi dalam upayanya memaksimalkan nilai-nilai budaya, konteks, keunikan, dan kecenderungan individu dalam suatu organisasi, serta atau upayanya dalam mengidentifikasi, menganalisis, mengadaptasi, dan menginovasi semua intervensi tren global secara inovatif dan kreatif, yang didasarkan pada nilainilai yang dianut.

\section{Revitalisasi Sistem Manajemen}

Eksistensi pesantren semakin diakui keabsahannya. Hal itu secara logis menghadirkan konsekuensi terhadap pengelola pesantren itu sendiri. Tantangan yang dihadapi salah satunya adalah menciptakan pesantren yang kompetitif. Agar mampu bersaing pesantren dituntut melaksanakan berbagai inovasi salah satunya melalui program SMP-BP, dimana pesantren berusaha memenuhi kekurangan dalam hal pembelajaran sains dan umum. Pimpinan pesantren Darul Amin bersifat visioner. Berpartisipasinya Darul Amin sebagai keanggotaan SMP BP merupakan salah satu ikhtiar Pimpinan pesantren dalam meningkatkan mutu di Bidang Sains. Apresiasi tersebut juga merupakan bentuk keterbukaan pimpinan terhadap perubahan yang terjadi. Meski demikian pesantren tetap berusaha mempertahankan nilai-nilai warisan terdahulu yang pembelajaran kitab. Oleh karena itu program SMP BP dilaksanakan di luar jam formal, yaitu dilaksanakan pada sore atau malam hari.

Sikap responsive tersebut juga karena pengelola menganggap pesantren merupakan subsistem dari sisdiknas sehingga terus membuka diri terhadap upaya pemerintah dalam hal revitalisasi pesantren asalkan masih dalam batas norma-noma pesantren. Sebenarnya program SMP-BP sangat bermanfaat bagi pesantren karena dalam pelaksanaan para guru difasilitasi dalam diklat sehingga mampu meningkatkan kompetensi di bidang sains. Selain itu pesantren juga mendapat bantuan berupa dana peningkatan unit usaha yang dapat disesuaikan dengan karakteristik daerah dan ketersediaan sdm yang dimiliki pesantren. Kondisi pesantren Darul Azhar tidak jauh berbeda dengan Darul Amin, tergabungnya SMP S Darul Azhar sebagai peserta program merupakan responsifitas dari keterbukaan pesantren terhadap perubahan. Peningkatan pada aspek sains juga merupakan mengakomodir harapan masyarakat terhadap kualitas anaknya setamat pesantren mampu bersaing masuk perguruan tinggi negeri yang notabene syarat utamanya adalah kemampuan di bidang sains.

Penilaian terhadap peningkatan kapasitas kelembagaan mengacu pada indicator keahlian dalam menguasai pada sejumlah bidang pengajaran tertentu. Pencapaian tujuan tersebut akan terlaksana dengan melakukan pembaharuan sistem manejemen. Membangun sistem di pesantren memerlukan proses berjangka karena berkaitan dengan seluruh komponen pesantren. Kehadiran budaya organisasi yang efektif akan memudahkan serta menguatkan penciptaan sistem manajemen, karena melalui budaya akan tertanam nilai-nilai organisasi pada masyarakat organisasi yang merubah paradigma serta pola pikir terhadap kepentingan pesantren. Hal tersebut selaras dengan penelitian yang dilakukan (Mardiyah, 2012) dan (Prasetyo, 2019). 
Pada prosesnya penciptaan budaya merupakan inisiasi dari manajer tingkat atas dalam struktur kelembagaan pesantren. Dalam penelitian ini berarti pendiri pesantren, kepala sekolah, para guru, coordinator departemen dan jajaran manajerial di pesantren. Pembenahan pesantren harus diawali dengan tekad untuk mewujudkannya pesantren yang unggul. Untuk itu perlu dukungan seluruh komponen termasuk guru dengan menunjukkan kinerja yang baik. Secara korelatif, apabila kinerja individu baik maka kinerja organisasi akan baik, selaras dengan penelitian yang dilakukan (Jansen, 2005) (Park et al., 2015).

\section{Komitmen Perubahan}

Kajian budaya tidak terlepas dari pemahaman tentang nilai warisan dalam sebuah organisasi. Di lain pihak masyarakat yang berada di dalam organisasi terus berubah sehingga nilai yang terwariskan juga ikut berubah. Dalam kasus ini, pengelola pesantren meski melaksanakan program SMP-BP tetap menjaga nilai kepesantrenan. Bagian pengajaran sebagai penanggungjawab masalah kurikulum tetap menjaga bahwa pelajaran bermuatan agama tetap menjadi prioritas. Masalahnya dengan adanya program SMP-BP menuntut jam tambahan untuk pelajaran sains.

Dalam penelitian ini diketahui bahwa bagian pengajaran memiliki strategi penambahan jam terkait program BP dilaksanakan di luar jam formal artinya pesantren dengan konsep boardingschoolnya melaksanakn pendidikan dan pengajaran selama 24 jam penuh sehingga pemenuhan jam tambahan dapat dilakukan pada waktu sore dan malam hari. Selain itu, jam tambahan hanya diterima oleh santri yang terpilih dan tergabung dalam kelas khusus sehingga pelajaran yang disampaiakan dapat diserap secara efektif dan efesien. Strategi tersebut menjadi bukti konkrit pesantren komit terhadap perubahan yaitu pelaksanaan program SMP-BP.

Melalui penelitian Cameron \& Green, (2009) dan proses pembentukan budaya organisasi memerlukan strategi perubahan karena dampak perubahan dan subkultur serta faktor eksternal yang membentuk budaya (Schein, 2008). Dalam teori perubahan, perlu adanya perubahan paradigma dalam hal pencapaian tujuan organisasi. Perspektif praktik yang digunakan dalam penelitian menghindari deskripsi jenis budaya umum dan hasil berdasarkan pengalaman, yang merupakan tantangan umum dalam penelitian budaya sekolah. Studi tersebut menyarankan para peneliti melakukan analisis praktik untuk menggambarkan kompleksitas dalam budaya sekolah dan peningkatan (Nehez \& Blossing, 2020). Isyarat-isyarat yang ditunjukkan dalam paparan teori perilaku organisasi antara lain budaya organisasi terbentuk sebagai penguat nilai dalam mencapai tujuan organisasi, oleh karena itu dibutuhkan keselarasan tujuan dan strategi, adanya persamaan asumsi dasar, sehingga organisasi berjalan stabil dan menjaga life cycle organisasi atau kelompok (Birnbaum, 2000).

Pada umumnya konstruks budaya organisasi yang sangat fundamental yang eksis di dalamnya cenderung konservatif dan juga memiliki nilai-nilai kekeluargaan, akan tetapi ia juga sangat menjunjung tinggi inovasi sebagai gerbang kemajuan organisasinya. Dari pola direfrensiasi ini sangat terlihat bahwa pada tingkat pertama yaitu yang tidak terlihat merupakan suatu tingkatan yang sangat sulit diubah (berubah), tetapi pada tingkat yang kedua yaitu yang tampak perubahan sangat mungkin untuk dilakukan, sehingga pola tingkah laku dan gaya anggota organisasi bertahan lama, kalau terjadi perubahan bukanlah sesuatu yang primer yang menyangkut nilai dan sistem (Bashori et al, 2020).

Perwujudan komitmen oleh top manajemen adalah penguatan terhadap budaya organisasi. Sebuah budaya organisasi yang kuat ketika ada komitmen bersama yang tinggi terhadap nilai-nilai inti, dan ia akan lemah ketika kontrol harus dilakukan melalui perintah administratif. Dalam membentuk komitmen perubahan perlu sebuah kerangka kerja, dalam kasus ini karena budaya organisasi memiliki korelasi yang kuat dengan alur gerak organisasi maka pesantren melaksanakan fungsi operatif, pesantren melakukan menyeimbangkan antara kemampuan beradaptasi terhadap eksternal (fungsi eksternal) dan integrasi masyarakat internal (fungsi internal). Proses adaptasi 
secara eksternal dilakukan terus-menerus sehingga pada akhirnya terjadi penyesuaian yang bermuara pada proses asimilasi atau akulturasi. Menjadi perhatian juga nantinya adalah terjadinya faktasitas. Semakjn kuat budaya maka tidak akan mudah dipengaruhi lingkungan atau budaya luar yang berkembang (Dappa et al., 2019).

Dalam konteks pesantren, perbedaan paradigma pengelola dalam menafsirkan ajaran Islam berdampak pada kebijakan yang dihasilkan. Kepala Sekolah mengkedepankan rasa husnudzon kepada Guru, sehingga lebih toleran dan mengalah. Pesantren menjadikan agama sebagai acuan nilai pembelajaran sehingga terbentuk rasa solidaritas pada setiap tingkatan kerja organisasi, para guru tidak perlu ada yang berkecil hati sehingga malas untuk berbuat. Perlu diciptakan kesadaran di mana masyarakat dalam organisasi merasa saling membutuhkan sehingga mengerti tentang tujuan dan tugas pekerjaan. Nilai yang dimiliki oleh organisasi untuk kebutuhan organisasi itu sendiri. Artinya, nilai-nilai yang ada dalam organisasi tersebut memiliki urgensitas tersendiri bagi perkembangan organisasi yang pada akhirnya terefleksikan dalam bentuk norma serta keyakinan dasar anggota organisasi (Brannen, 2004).

\section{Pendekatan dan Karakteristik Budaya Organisasi}

Budaya organisasi didefinisikan sebagai kerangka kerja kognitif yang berisi sikap, nilai, norma perilaku, dan ekspektasi (harapan) yang dimiliki oleh anggota organisasi (Greenberg \& Barton, 2003). Sementar itu Gibson et al., memberikan batasan konsep bahwa budaya organisasi merupakan nilai yang dirasakan anggota organisasi dan bagaimana persepsi ini membentuk nilai-nilai serta menciptakan pola keyakinan akan sebuah harapan.

Karakteristik budaya organisasi di sekolah, yaitu mengamati keteraturan perilaku penanaman norma; nilai dominan; filosofi kelembagaan; aturan dan disiplin, dan iklim organisasi. (Aquinas, 2006). Karakteristik tersebut menjadi penunjang bangunan budaya organisasi di sekolah dengan jenis budaya yaitu budaya entrepreneurial dan budaya administratif. Berbeda dengan Robbins dan Coulter, (2016) mengelompokkan budaya organisasi menjadi empat kriteria (tipe), yaitu budaya kerja (networked culture), budaya pasukan (mercenary culture), budaya fragementasi (fragmented culture), dan budaya komunal (communal culture). Dari kerangka inilah kemudian hasil penelitian menunjukkan bahwa budaya organisasi dalam membangun kinerja organisasi pada tataran aspek berikut (1) memberikan rasa identitas kepada organisasi, dengan adanya program BP menjadi penguatan kompetensi di bidang sains; (2) komitmen terhadap visi misi organisasi; (3) membentuk standar perilaku masyarakat pesantren; dan (4) peningkatan stabilitas sistem sosial; (5) pengembangan sumber daya insasi; dan (6) pembenahan dalam hal struktur manajemen.

Komponen Budaya Pesantren yang terdiri dari norma dan nilai membentuk seperangkat acuan dalam menjalani dinamika kerja pesantren. Karakteristik budaya kerja yang negative adalah terciptanya toleransi dan solidaritas secara berlebihan sehingga tidak mampu membedakan mana dunia kerja dan dunia pertemanan sehingga mengakibatkan penurunan kinerja organisasi. Sebaliknya apabila tercipta organisasi dengan tipe fragmented yang ditandai dengan tingginya sosiabilitas dan kesenangan sehingga lalai terhadap target yang sudah dicanangkan. Program SMPBP merupakan program dengan Batasan waktu, artinya pesantren dapat terfasilitasi dalam peningkatan sains hingga terbentuk sebuah sistem yang kemudian diteruskan oleh pengelola pesantren. Bentuk kebersamaan adalah dalam pelaksanaan adalah menciptakaan network culture persahabatan. Dalam hal ini guru dalam pembelajaran bersifat terbuka dalam hal sosalisasi dan meluangkan waktu untuk santri yang tidak faham akan pelajaran. Pembelajaran yang dilaksanakan juga tidak bersifat satu arah, artinya santri yang terliat merasa penting dan dilibatkan sehingga merasa bahwa mereka adalah bagian dari kelompok.

Eksternalitas yang ada relasinya dengan eksistensi organisasi. Secara empiris normatif, pembentukan budaya organisasi pertama kali dikonstruksi oleh pendiri (founders) atau pimpinan paling atas (top management). Dalam strukturisasi pesantren pendiri tergabung dalam struktur Yayasan sedangkan top manager ketua atau pimpinan pesantren yang terlibat dala operasionalisasi pesantren. Besarnya pengaruh yang dimiliki mereka akan menentukan cara (metode), keyakinan, 
perilaku, dan tindakan yang dijalankan dalam organisasi yang dipimpinnya. Secara garis besar proses pembentukan budaya organisasi oleh dua komponen pkok yaitu pengaruh pendiri (founder) dan dampak pemimpin (leader). Tindakan pimpinan puncak akan membentuk ikim umum mengenai perilaku yang dapat diterima. Pimpinan tidak hanya memperhatikan nilai mana yang diterima, diyakini, dikuasai, dan menjadi komitmen kepala sekolah tetapi juga kebenaran yang harus dijaga ketat oleh semua tim sekolah.

Di sisi yang lain, bagaimana bentuk sosialisasi sangat bergantung pula pada kesuksesan yang dicapai dalam menerapkan nilai-nilai pada proses seleksi. Ketika mengikuti alur dari proses terbentuknya budaya organisasi dapat dikatakan bahwa pemimpin transformatif menempati posisi yang sangat strategis dalam mengaktualisasikan ide-ide perubahan. Gesekan terhadap eksternal tidak dapat dihindari, proses ini disebut tahap evousi dimana organisasi secara gradualistik mengalami pergeseran nilai kemudian secara selektif nilai tersebut mengalami penyesuaian hingga pada gilirannya tiba akan muncul budaya organisasi yang diharapkan, meski proses perubahan atau transformasi akan memakan waktu relatif lama dan mahal (Amstrong \& Duncan Brown, 2019). Begitulah sebuah pembangunan budaya organisasi mengacu pada filsafat orang-orang yang berstatus pendiri atau pimpinannya. Pada proses selanjutnya, budaya organisasi akan sangat dipengaruhi oleh kriteria yang digunakan dalam penerimaan dan juga ketika memperkerjakan karyawan.

\section{Membangun Budaya Organisasi}

Dalam menyonsong pembangunan budaya yang terintegrasi, maka pesantren secara integrative melibatkan guru maupun tenaga kependidikan. Keunggulan pesantren dalam penerapan sistem berasrama membentuk perilaku kerja yang kolaboratif. Proses koordinasi terhadap capaian program juga tidak hanya dilakukan pada pertemuan formal, melainkan lebih sering dilakukan secara operatif dilapangan.

Pelaku-pelaku yang akan tertibat dalam pengembangan adalah berasal dari guru, karyawan dan santri itu sendiri. Jenjang pendidikan formal SMP secara hirarki struktur kelembagaan berada dibawah pesantren, oleh karena itu faktor kepemimpinan pesantren sangat menentukan jalannya program. Baik Darul Amin maupun Darul Azhar pimpinan sama-sama mendukung proses perubahan yang inovatif.

Mengacu pada konsepsi yang dipaparkan Haskett, terdapat dua tingkatan dalam bangunan budaya organisasi yaitu (1) bersifat hidden (tidak nampak), proses yang terbentuk dimulai dari keyakinan terhadap nilai yang dianut Bersama kemudian membentuk sebuah perilaku individu kemudian perilaku kelompok; (2) perilaku memunculkan nilai, dapat diamati dari tindakan yang menjadi kebiasaan; sampai ada anggota baru yang masuk kemudian mengikuti perilaku yang membudaya (Kotter \& Heskett, 2011). Dalam kasus penelitian miliu pembelajaran sains yang sudah familiar akan menarik atensi para santri kemudian menjadi stimulus untuk mendalami bidang tersebut.

Pengelolaan pesantren dilihat dari sudut pandang sistem adalah perhatian terhadap aspek input-proses dan output. Dalam proses pendidikan yang dilaksanakan terasa kuat apabila pesantren memiliki sistem yang menjamin budaya pesantren tersebut karena pada prinsipnya budaya organisasi menjadi bagian dari proses pendidikan pesantren. Budaya organisasi yang dilaksanakan juga menunjukkan identitas pesantren sehingga membedakan antara satu dengan lainnya. Pesantren yang memiliki budaya yang kuat dapat menjadi proteksi terhadap tantangan yang berkembang dari luar organisasi. (J. Hogan \& V.Coote, 2014).

Budaya kekuasaan menjadi tempat kunci dari keseluruhan organisasi berada di tengah-tengah seperti jaring laba-laba, biasanya didominasi oleh figure karismatik atau pendiri, dalam hal ini kepribadian lebih penting dari struktur formal. Budaya tugas, fokus utama terletak pada penyelesaian pekerjaan atau projek dengan anggapan bahwa pencapaian tujuan organisasi lebih 
penting dari kepentingan apapun. Budaya seseorang adalah kesesuaian individu terhadap kepentingan organisasi. individu menempatkan minat mereka sebagai hal utama dan organisasi sebagai batu pijakan. Budaya peran adalah fokus pokok suatu tindakan kepribadian antara pimpinan dan bawahan yang menyatakan bahwa organisasi dipandang sebagai serangkaian peran yang saling berkaitan dengan proses komunikasi cenderung diformalkan menjadi sistem dan proses.

Dalam kasus penelitian, pembentukan budaya organisasi mengarah kepada penciptaan miliu pembelajaran sains. Hal tersebut sebagai manifes dari pelaksanaan program SMP-BP. Aktualisasi yang dapat dipaparkan melalui hasil penelitian adalah, pertama, kontribusi pendiri organisasi, karena berada dalam struktur Yayasan dan tidak secara langsung terjun pada hal yang sifatnya operatif maka pembentukan budaya dapat dimulai oleh Pimpinan pesantren dengan menerapkan serangkaian kebijakan yang mendukung terhadap efektivitas pelaksanaan program. Pimpinan pesantren juga memiliki kepribadian dinamis, nilai yang kuat, dan memiliki visi yang jelas tentang bagaimana organisasi merespon terhadap pelaksanaan program. Dalam hal ini pimpinan pesantren mempercayakan sepenuhnya pada kepala sekolah SMP sebagai coordinator lapangan. Kedua, perlu pengalaman dalam menghadapi lingkungan eksternal. Tantang lingkungan eksternal bagi pesantren adalah daya kompetisi di bidang sains. Oleh sebab itu penghargaan sekolah di pesantren perlu mengarah pada pengembangan pembelajaran sains dan kewirausahaan yang tercermin dalam berbagai sikap dan nilai. Ketiga menciptakan hubungan kerja antara guru dan santri sehingga kesuksesan pelaksanaan program bersifat dua arah guru yang memberikan maeteri dan santri yang ikhlas menerima materi.

Budaya yang sudah terbentuk mewariskan nilai. Nilai yang berjalan teraktualisasi dalam sikap masyarakat pesantren. Dengan adanya guru atau karyawan baru maka secara bertahap nilai tersebut secara perlahan dipercaya dan diikuti atau bahkan setelah pendirinya meninggalkan organisasi. Penguatan jalinan tersebut juga merupakan perwujudan harapan, nilai, sikap ke dalam organisasi. Kuatnya ikatan kerja juga tercermin dari aktivitas utama dalam pelaksanaan program SMP-BP. Akhirnya pembentukan budaya organisasi dipengaruhi seluruh komponen yang terlibat di mana organisasi beroperasi serta hakikat dari organisasi tersebut.

\section{Efektivitas Organisasi}

Dalam kajian perilaku organisasi penguatan terhadap budaya organisasi adalah hal yang bersifat asasi. Agar sistem manajemen berjalan optimal perlu dukungan budaya organisasi. Budaya tidak muncul secara otomatis melainkan perlu diciptakan dipelihara, dan diperkuat agar konsisten terhadap perubahan eksternal dan tuntutan internal. Asumsi tersebut sejalan dengan penelitian relevan yang dilakukan Zwell, (2000) dan (Prasetyo et al., 2020) yang juga menyatakan bahwa budaya organisasi yang kuat secara korelatif mampu meningkatkan antuasiasme, komitmen, serta loyalitas masyarakat organisasi sehingga berdampak positif terhadap lembaga pendidikan. Efektivitas penerapan program SMP-BP pada pesantren Aceh Tenggara terlihat dari beberapa unit usaha yan didirikan serta capaian akademis pada jenjang formal SMP dimana pesantren Darul Amin maupun Darul Azhar memperoleh juara pada event perlombaan sains di tingkat Kabupaten.

Budaya organisasi mampu membentuk perilaku serta sikap anggota organisasi yang dibingkai oleh pencapaian tujuan dan visi organisasi. Walaupun demikian, embrionikal budaya organisasi tidak serta merta muncul menjadi bagian dari organisasi, tetapi ia ditata, dirancang, dan dibangun atas dasar tujuan, keyakinan, serta nilai-nilai fundingfather organisasi. Selain komitmen terhadap perubahan, akan menyajikan konsep sistem Pesantren dalam perspektif budaya sebagai variabel.

Melalui hasil penelitian, pesantren Darul Amin dan Darul Azhar sudah efektif dalam melaksanakan program SMP-BP. Efektivitas tersebut tidak terlepas dari penguatan budaya pesantren dalam implementasi program. Budaya organisasi sebagai variabel kunci dilaksanakan melalui serangkaian tahapan berikut, perhatian pada mekanisme kepemimpinan; pelaksanaan revitalisasi manajemen; pembentukan komitmen terhadap perubahan serta pengembangan terhadap bangunan budaya pesantren yang terdiri dari penguatan nilai-nilai organisasi. 


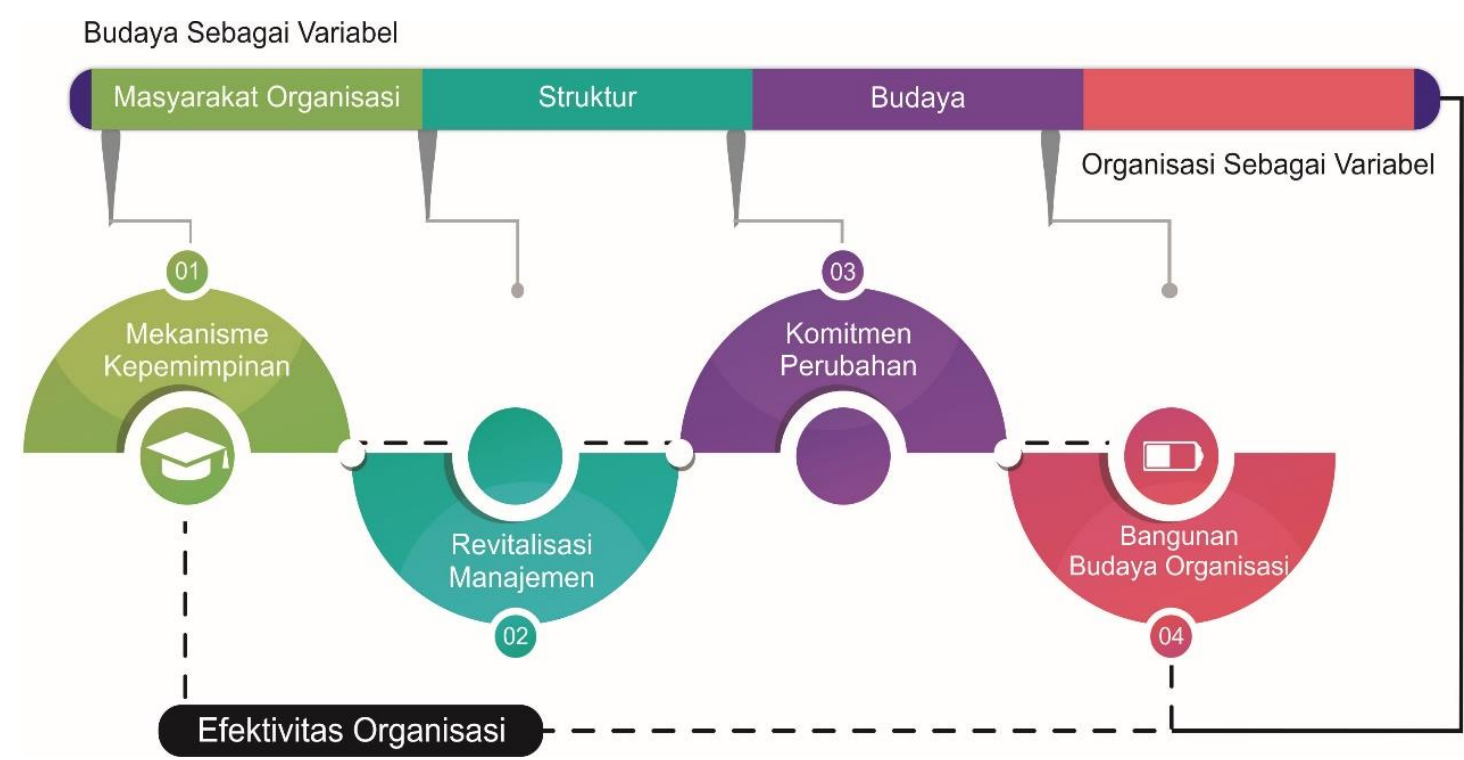

\section{Gambar 1: Novelty Penelitian, Efektivitas Organisasi Melalui Budaya Organisasi}

Dalam kasus ini pesantren sebagai pelaksana program SMP-BP dituntut untuk menciptakan sistem sehingga program dapat berjalan berkesinambungan. Koherensinya, budaya organsiasi sebagai faktor determinan memilikis serangkaian proses yang harus dilaksanakan seperti pada gambar novelty. Gambar 1 menerangkan pendekatan budaya organisasi terhadap efektivitas organisasi dalam bangunan konsep penelitian. Tahapan bangunan menekankan pada mekanisme kepemimpinan, revitalisasi manajemen dan komitmen perubanan. Budaya sebagai variabel menunjukkan peran krusial menjadi perekat antar warga organisasi. Sedangkan organisasi sebagai variabel menaruh perhatian pada aspek perilaku masyarakat organisasi, struktur organisasi dan budaya. Budaya organisasi rentan terhadap perubahan mengikuti karaktersitik masyarakat organisasi. Sebaliknya pesantren dengan budaya yang kuat akan membentuk kesamaan perilaku sehingga fokus terhadap visi tetap terjaga. Kesamaan perilaku membawa individu yang berbeda agar muncul Kerjasama dalam sebuah tim kerja. Apabila kebersamaan hilang maka akan terpecah dan berpotensi menyebabkan organisasi musnah. Untuk itulah perlu strategi perubahan sebagai langkah kuratif dalam gambar 1 novelty di atas.

Hasil menunjukkan proses penerapan yang dilakukan pesantren Darul Amin adalah melalui penguatan budaya organsiasi. Begitu juga pesantren Darul Azhar, melalui penguatan nilai-nilai serta perubahan paradigma pimpinan dalam merespon perubahan juga berperan sentral dalam efektivitas penerapan program SMP-BP. Walaupun demikian, embrionikal budaya organisasi tidak serta merta muncul menjadi bagian dari organisasi, tetapi ia ditata, dirancang, dan dibangun atas dasar tujuan, keyakinan, serta nilai-nilai fundingfather organisasi, para pendiri -ketua Yayasan-. Dalam konteks pesantren nilai tersebut menjadi acuan dalam formalisasi lembaga mencangkup Anggaran Dasar Rumah Tangga (AD-ART) serta Rencana Strategis.

Budaya merupakan proses implementasi nilai. Sebuah nilai akan kuat apabila terjadi harmonisasi antar elemen pendukung internal organisasi. Hal tersebut akan terwujud dengan sebuah strategi komunikasi interpersonal yang efektif serta pengamalan nilai-nilai Islam dapat dicapai dengan kegiatan silaturahmi, hasil penelitian didukung oleh penelitian relevan yang dilakukan oleh Sensuse et al, (2015) dan (Anwar, 2021). Pihak pengelola pesantren mencermati terjadinya potensi konflik akibat intensitas program pesantren yang begitu padat. Mengacu pada teori (Rahim, 2013) dan (Blank, 2019) secara bersama menyatakan bahwa konflik saat ini dibutuhkan oleh organisasi agar efektif. Hal tersebut secara korelatif menyatakan pelaksanaan hubungan antara budaya organisasi dengan efektivitas organisasi berimplikasi pengelolaan konflik 
yang optimal akan berdampak fungsional, dan tingkat konflik sangat fungsional berdampak pada efektivitas organisasi. Sebaliknya apabila konflik yang muncul terlalu rendah maka organisasi menjadi tidak efektif dan mengalami stagnasi. Akibatnya organisasi menjadi lambat dalam beradaptasi dengan berbagai perkembangan lingkungan. Perlu diperhatikan juga apabila tingkat konflik terlalu tinggi, maka akan timbul kekacauan, tidak kooperatif, dan menghalangi pencapaian efektivitas organisasi (Robertson, 2003) (Mukhtar, 2020).

Nilai-nilai kepemimpinan tersebut akhirnya menginspirasi berkembangnya budaya sekolah yang kuat yang menjadi fondasi kuat bagi sistem sekolah, sebagaimana kesimpulan penelitian (Liljenberg, 2014) (Fishman, 2009). Ketika kepemimpinan berhasil diintegrasikan ke dalam budaya sekolah dan memperkuat sistem sekolah, sekolah akan berhasil tanpa adanya kegagalan, terutama kegagalan suksesi tertentu (pergantian kepala sekolah). Secara praktis, hal ini terjadi karena kekuatan sistem sekolah yang dimulai dari nilai-nilai kepemimpinan yang baik yang menumbuhkan kualitas program sekolah dalam berbagai aspek

Lembaga pendidikan Islam pesantren terkenal dengan penanaman nilai-nilai keikhlasan. Implikasi yang diharapkan agar pengelola pesantren mempertahankan nilai warisan budaya pesantren seperti nilai keikhlasan. Penjagaan terhadap nilai tersebut menjadikan pesantren memiliki shared values yang tinggi dalam membangun budaya organisasi. Konstruks budaya organisasi yang sangat fundamental yang eksis di dalamnya cenderung konservatif dan juga memiliki nilai-nilai kekeluargaan, akan tetapi ia juga sangat menjunjung tinggi inovasi sebagai gerbang kemajuan organisasinya.

Pesantren akan efektif dalam membangun budaya apabila merekrut sumber daya unggul menjadi guru, dalam hal ini Darul Amin menjadikan syarat utama rekrutmen guru adalah memiliki latar belakang pendidikan pesantren mengacu pada nilai-nilai pesantren yang hanya dapat dirasakan tidak melihat spontanitas kemudian faham akan pesantren. Kemudian pihak pesantren mewajibkan guru untuk tinggal di pesantren alasannya pembentukan lingkungan kerja yang nyaman dan kondusif untuk bekerja dan mendorong mereka untuk berkarya agar mereka tidak kehilangan fokus kemudian mencari pekerjaan lain untuk memenuhi kebutuhannya.

Konsekuensi logis apabila program dapat bermanfaat secara berkesinambungan maka pihak pesantren perlu melakukan perencanaan dalam rekrutmen guru yang bermutu prima dalam bidang sains. Kalau tidak maka keberlangsungan program BP hanya akan menghasilkan lulusan-lulusan yang stagnan. Apapun perubahan dan inovasi pendidikan yang hendak dilakukan oleh pesantren kalau mutu guru rendah maka semuanya akan sia-sia.

Dasar dari hasil penelitian ini menyatakan bahwa eksistensi keberhasilan program SMP-BP sangat tergantung pada kapasitas atau kemampuan lembaga dalam melakukan adaptasi terhadap tekanan yang muncul akibat perubahan yang muncul di lingkungan, hasil penelitian selaras dengan kajian yang dilakukan oleh (Elsmore, 2017) (Dull, 2010). Dengan demikian, peran budaya organisasi pesantren secara teoretis adalah memberikan core organizational value bagi suatu organisasi yang tercermin dari kebebasan atau ketertarikan para anggota organisasi untuk memberikan ide-ide baru, kemauan menerima risiko-risiko yang mungkin saja terjadi, dan keterbukaan untuk dapat melakukan komunikasi secara bebas dan bertanggung jawab. Pada akhirnya ada beberapa saran untuk menggerakkan Pesantren melalui pendekatan sistem, dengan harapan tujuan pesantren dapat tercapai secara efektif dan efisien. Sistem pesantren dengan poin komprehensif. Selanjutnya pemahaman parsial ini berimplikasi pada pembangunan parsial dari pada pembangunan yang diharapkan tidak optimal. Strategi pesantren, manajemen perubahan, manajemen sumber daya manusia, struktur organisasi, dan strategi pembelajaran.

\section{SIMPULAN}

Pesantren di Aceh Tenggara terbilang efektif dalam melaksanakan program SMP-BP. Budaya organisasi berperan sebagai faktor fundamental dalam pencapaian tersebut. Budaya organisasi yang sarat akan nilai dirancang dan dibangun oleh Pimpinan pesantren. Walaupun demikian, embrionikal budaya organisasi tidak serta merta muncul menjadi bagian dari organisasi, tetapi ia 
ditata, dirancang, dan dibangun atas dasar tujuan, keyakinan, serta nilai-nilai yang merupakan elemen kunci dalam bangunan budaya organisasi. Realtias yang terjadi budaya organisasi pesantren dalam penciptaan miliu pembelajaran sains (implementasi program SMP-BP) sangat dominan pengaruhnya terhadap efektiftivitas organisasi melalui mekanisme kepemimpinan, revitalisasi sistem, komitmen perubahan dan pengembangan budaya organisasi. Penelitian ini berimplikasi terhadap pengembangan model budaya organisasi kontekstual dan konseptual pada dinamika pengelolaan pendidikan saat ini. Implikasi social penelitian menjadi suplemen pelaksanaan manajemen mutu berkelanjutan sebagai nilai budaya institusi pesantren, selain sebagai konsep operasional.

\section{DAFTAR PUSTAKA}

Abubakar, A. M., Elrehail, H., Alatailat, M. A., \& Elçi, A. (2019). Knowledge Management, DecisionMaking Style and Organisational Performance. Journal of Innovation \& Knowledge, 4(2), 104114. https://doi.org/10.1016/j.jik.2017.07.003

AL-Abrrow, H., Abdullah, H., \& Atshan, N. (2019). Effect of Organisational Integrity and Leadership Behaviour on Organisational Excellence: Mediator Role of Work Engagement. International Journal of Organizational Analysis, 27(4), 972-985. https://doi.org/10.1108/IJOA-o8-20181518

Alam, N. A. R. (2018). Strengthening Leadership Culture (The Role of Kyai in Indonesian Pesantren). At-Ta'dib, 13(1), 5-17.

Amstrong, M., \& Duncan Brown. (2019). Strategic Human Resource Management: Back to The Future. www. employment-studies. co. uk/system/files/resources/files/517_Strategic-HumanResource-Management-Back-to-the-future-IES-CIPD-2019. pdf.

Aquinas, P. G. (2006). Organisational Behaviour: Concepts, Realities, Applications and Challenges. Excel Books India.

Arikunto, S. (2019). Dasar-Dasar Evaluasi Pendidikan (3rd ed.). Bumi Aksara.

Asrori, S. (2020). Lanskap Moderasi Keagamaan Santri, Refleksi Pola Pendidikan Pesantren. Jurnal Ilmu Sosial Indonesia, 1(1), 16-26. https://doi.org/10.15408/jisi.v1i1.17110

Bashori, B., Prasetyo, M. A. M., \& Susanto, E. (2020). Change Management Transformation in Islamic Education of Indonesia. Social Work and Education, 7(1), 72-85.

Birnbaum, R. (2000). The Life Cycle of Academic Management Fads. The Journal of Higher Education, 71(1), 1-16.

Blank, S. (2019). Managing Organisational Conflict. McFarland Publisher.

Brannen, M. Y. (2004). People in Global Organisations: Culture, Personality, and Social Dynamics. In Henry W. Lane, dkk. (Ed it ), The Blackwell Handbook of Global Management: A Guide to Managing Complexity. Blackwell Publishing Ltd.

Bungin, M. B. (2018). Penelitian Kualitatif, Komunikasi, Ekonomi, Kebijakan Publik, dan Ilmu Sosial Lainnya, Edisi Kedua. Kencana Prenada Media Grup.

Cacciattolo, K. (2014). Understanding Organisational Cultures. European Scientific Journal, 2(1), $1-7$.

Cameron, E., \& Green, M. (2009). Making Sense of Change Management (2nd Editio). Kogan Page.

Cresswell, J. W. (2012). Educational Research, Planning, Conducting, and Evaluating Quantitative and Qualitative Research. Pearson Merrill Prentice Hall.

Dacholfany, M. I. (2015). Leadership Style in Character Education at The Darussalam Gontor Islamic Boarding. Al-Ulum, 15(2), 447. https://doi.org/10.30603/au.v15i2.212

Dana Indra Sensuse, Cahyaningsih, E., \& Wibowo, W. C. (2015). Knowledge Management: Organizational Culture in Indonesian Government Human Capital Management. Procedia Computer Science, 72, 485-494. https://doi.org/10.1016/j.procs.2015.12.130

Dappa, K., Bhatti, F., \& Aljarah, A. (2019). A Study on the Effect of Transformational Leadership on Job Satisfaction: The Role of Gender, Perceived Organizational Politics and Perceived Organisational commitment. Management Science Letters, 9(6), 823-834.

Dull, M. (2010). Leadership and Organizational Culture: Sustaining Dialogue between Practitioners and Scholars. Public Administration Review, 7o(6), 857-866.

Elsmore, P. (2017). Organisational Culture: Organisational Change?: Organisational Change? Routledge. 
Fajar, A. M. (2011). Madrasah dan Tantangan Modernitas. Mizan Pustaka.

Fauziah, N. (2018). Kompetensi Manajerial Kepala Sekolah Dalam Mengembangkan Pendidikan Agama Islam Berwawasan Multikultural. JMPI: Jurnal Manajemen Pendidikan Islam, 3(1), 10-26. https://doi.org/10.1886o/jmpi.v3i1.6250

Green, T. J. (2012). TQM and Organisational Culture: How do they Link? Total Quality Management \& Business Excellence, 23(2), 141-157.

Greenberg, J., \& Barton, R. A. (2003). Behavior in Organizational. Prentice Hall International.

Hasyim, H. (2015). Transformasi Pendidikan Islam (Konteks Pendidikan Pondok Pesantren). Jurnal Pendidikan Agama Islam-Ta'lim, 13(1), 57-77.

Hidayah, U., \& Prasetiya, B. (2019). Multicultural Education in Madrasah Diniyah As Prevention of Religious Conservatism. JURNAL TARBIYAH, 26(1). https://doi.org/10.30829/tar.v26i1.417

Hinde, R. A., \& Stringer, C. B. (2012). Culture Evolves. Oxford University Press.

Indra, H. (2017). Salafiyah Curriculum at Islamic Boarding School in the Globalization Era. TARBIYA: Journal of Education in Muslim Society, 4(1), 74-88.

J. Hogan, S., \& V.Coote, L. (2014). Organizational Culture, Innovation, and Performance: A Test of Schein's Model. Journal of Business Research, 67(8), 1609-1621. https://doi.org/10.1016/j.jbusres.2013.09.007

Jansen, J. D. (2005). Targeting Education: The Politics of Performance and the Prospects of "Education For All." International Journal of Educational Development. https://doi.org/10.1016/j.ijedudev.2005.04.009

Jerald, C. D. (2012). Movin'It" and" Improvin'It! Using Both Education Strategies to Increase Teaching Effectiveness. Center for American Progress.

Kantavong, P. (2018). Understanding Inclusive Education Practices in Schools under Local Government Jurisdiction: a Study of Khon Kaen Municipality in Thailand. International Journal of Inclusive Education, 22(7), 767-786. https://doi.org/10.1080/13603116.2017.1412509

Kotter, J. P., \& Heskett, J. L. (2011). Corporate Culture and Performance. The Free Press.

Lassnigg, L. (2017). Competence-Based Education and Educational Effectiveness. In Competencebased Vocational and Professional Education (pp. 667-693). Springer.

Liedtka, J., \& Kaplan, S. (2019). How Design Thinking Opens New Frontiers for Strategy Development. Strategy \& Leadership.

Marcia, J. E., Waterman, A. S., Matteson, D. R., Archer, S. L., \& Orlofsky, J. L. (2012). Ego Identity: A Handbook for Psychosocial Research. Springer Science \& Business Media.

Mardiyah, M. (2012). Kepemimpinan Kiai dalam Memelihara Budaya Organisasi di Pondok Modern Gontor, Lirboyo Kediri, dan Pesantren T ebuireng Jombang. Tsaqafah, 8(1), 67-104.

Mukhtar, H., \& Prasetyo, M. A. M. (2020). Pesantren Efektif Model Teori Integratif Kepemimpinan-Komunikasi-Konflik Organisasi. Deepublish.

Mukhtar, Risnita, \& Anwar, K. (2019). The Effect of Transformational Leadership, Management Information System, and Organizational Climate on Lecturers' Job Satisfaction. International Journal of Scientific and Technology Research.

Nehez, J., \& Blossing, U. (2020). Practices in Different School Cultures and Principals' Improvement Work. International Journal of Leadership in Education, 1-21. https://doi.org/10.1080/13603124.2020.1759828

Park, S. M., Miao, Q., \& Kim, M. Y. (2015). The Role of Leadership Behaviors for Enhancing Organisational Effectiveness in the Chinese Public Sector. International Review of Public Administration, 2O(2), 153-176. https://doi.org/10.1080/12294659.2015.1040204

Pertiwi, A. K., Cahyani, S. S. A., Diana, R. C., \& Gunawan, I. (2018). The Leadership of Kyai: A Descriptive Study. 3rd International Conference on Educational Management and Administration (CoEMA 2018), 121-126.

Prasetyo, M. A. M. (2019). Pengaruh Kepemimpinan Transformasional dan Budaya Organisasi Terhadap Pengelolaan Pendidikan Kecakapan Hidup di Ponpes Sholahuddin Al-Munawarah Gayo Lues. Ziryab: Jurnal Pendidikan Islam, 1(1), 90-104.

Prasetyo, M. A. M., \& Anwar, K. (2021). Karakteristik Komunikasi Interpersonal serta Relevansinya dengan Kepemimpinan Transformasional. Jurnal Komunikasi Pendidikan, 5(1). https://doi.org/10.32585/jkp.v5i1.1042

Prasetyo, M. A. M., Bashori, B., \& Masriani, M. (2020). Model Capacity Building Pada Pesantren Perbatasan Binaan Dinas Pendidikan Dayah Provinsi Aceh. INFERENSI: Jurnal Penelitian Sosial Keagamaan, 14(1), 71-96. https://doi.org/10.18326/infsl3.v14i1.71-96 
Rahim, A. (2013). Toward A Theory of Managing Organisational Conflict. The International Journal of Conflict Management, 13(3), 206-235.

Recepoğlu, E. (2013). Analysing the Relationship between Prospective Teachers' Life Satisfaction and Attitudes Concerning Teaching Profession. HU Journal Of Education, 1, 311-326.

Robbins, S. P., \& Coulter, M. (2016). Management. Prentice Hall.

Robertson, I. T., Callinan, M., \& Bartram, D. (2003). Organisational Effectiveness: the Role of Psychology. John Wiley \& Sons.

Schein, E. H. (2004). Organisational Culture and Leadership (Third Edit). Jossey Bass Publishers.

Schein, E. H. (2008). From Brainwashing to Organization Therapy, The Evolution of a Model of Change Dynamics. In Handbook of Organization Development (pp. 39-66). Sage Publication Inc.

Sergiovanni, T., \& Green, R. (2015). Characteristics of Successful Schools. Boston, MA: Allyn \&.

Subagia, S. (2010). Gagasan Liberalisasi Pendidikan Islam (1st ed.). Madani.

Tolchah, M., \& Arfan Mu'ammar, M. (2019). Islamic Education in The Globalization Era: Challenges, Opportunities, and Contribution Of Islamic Education in Indonesia. Humanities \& Social Sciences Reviews, 7(4), 1031-1037. https://doi.org/10.18510/hssr.2019.74141

Turner, B. A. (1983). The use of Grounded Theory for the Qualitative Analysis of Organizational Behaviour. Journal of Management Studies, 2O(3), 333-348.

Zwell, M. (2000). Creating a Culture of Competence. Willey \& Son Inc. 